\title{
The Effect of Olive Oil (Extra Virgine Olive Oil) and Moderate-Intensity Exercise On The Level of High Density Lipoprotein (HDL) in Male Wistar Strain Rat (Rattus novergicus L) Which Was Given High Fatty Diet
}

\author{
Ikhsan Syakban Anwari Siregar ${ }^{1}$, Hendra Sutysna ${ }^{2}$ \\ 1) Medical Study Program, Faculty of Medicine, University of Muhammadiyah of North Sumatra \\ 2) Anatomy Department, Faculty of Medicine, University of Muhammadiyah of North Sumatra \\ *Corresponding author: ikhsan.anwari99@gmail.com
}

\begin{abstract}
Background: Dyslipidemia is a condition where there is an abnormal lipid profile in the blood. Modern patterns and lifestyles such as consuming fast food cause excessive fat consumption which can increase the possibility of contracting blood vessel and heart disease. High levels of High Density Lipoprotein (HDL) cholesterol can protect the body against heart disease and stroke, but not many drugs can increase HDL cholesterol levels. Olive oil is an oil that contains 77\% Mono Unsaturated Fatty Acid (MUFA) which can reduce LDL cholesterol and increase HDL cholesterol. Objective: To determine the effect of olive oil (Extra Virgine Olive OilEVOO) and moderate intensity exercise on high density lipoprotein (HDL) levels in male Wistar strain (Rattus novergicus L) rats fed a high-fat diet. Method: a true experimental research design with a pretest and posttest design with a control group (Pretest and Posttest with Control Group) with simple randomization. Results: There was an increase in HDL levels in the control group ( 42.50 to $44.50 \mathrm{mg} / \mathrm{dL}$ ), the olive oil treatment group was (50.83 to 53.33) $\mathrm{mg} / \mathrm{dL}$, the moderate intensity exercise treatment group (46.67 to $52,00 \mathrm{mg} / \mathrm{dL}$ ), and the moderate-intensity exercise and olive oil treatment groups (47.50 to $58.67 \mathrm{mg} / \mathrm{dL}$ ). Conclusion: Extra Virgine Olive Oil, moderate intensity exercise, and Extra Virgine Olive Oil with moderate intensity exercise influence the increase of HDL levels in the blood of male Wistar strain rats fed a high-fatty diet.
\end{abstract}

Keywords: Dyslipidemia, Olive Oil, Exercises, HDL.

\section{INTRODUCTION}

Dyslipidemia is a condition where there are abnormalities of lipid profile in the blood such as an increase in total cholesterol, Low Density Lipoprotein (LDL), triglycerides, and a decrease in High Density Lipoprotein (HDL) cholesterol. Increased non-HDL lipid levels cause constriction of blood vessels or atherosclerosis. If the narrowing occurs in the coronary arteries then CHD can occur (1).
Heart disease is the number one cause of death and disability in the world. The Prediction of the World Health Organization (WHO) states that in 2015, this disease remains the leading cause of death that attacks around 20 million people worldwide. Then it will increase in 2030 to 23.6 million $(2,3)$.

In developing countries from 1990 to 2020 , death rates from coronary heart disease will increase $137 \%$ in men and 
$120 \%$ in women, while in developed countries the increase is lower at $48 \%$ in men and $29 \%$ in women. In 2020 cardiovascular disease is estimated to cause 25 deaths each year (4).

Cardiovascular disease is one of the leading causes of death in Indonesia, the prevalence of coronary heart disease in Indonesia, the majority of which is based on interviews with symptoms of the disease, a magnitude of $1.5 \%$. Based on data from the Household Health Survey in 2005 deaths from heart and blood vessel disease in hospitals in Indonesia amounted to $16.7 \%$. Meanwhile, the prevalence of dyslipidemia based on total cholesterol concentration> $200 \mathrm{mg} / \mathrm{dL}$ is $39.8 \%(4,5)$.

Modern patterns and manifestations such as consuming fast food, are increasingly becoming a culture in society. This phenomenon causes a tendency that can be detrimental, because excessive fat consumption can increase the likelihood of contracting blood vessels and heart disease (6).

High levels of High Density Lipoprotein (HDL) cholesterol can protect the body against heart disease and stroke, but there aren't many medicines that can increase HDL cholesterol levels. The currently available HDL cholesterol enhancing drug is a high-dose niacin, which can increase HDL cholesterol levels by around $20 \%$. But it has side effects, such as skin redness and itching, interference with the gastrointestinal tract, also increasing insulin resistance. So it needs a new strategy that can reduce levels of Low Density Lipoprotein (LDL) cholesterol while increasing HDL cholesterol levels $(7,8)$. Another effort that strongly supports accelerating the balance of HDL and LDL levels is to do the right type of physical exercise and plant consumption that can reduce cholesterol levels (6).

Based on research in the Middle East and Mediterranean countries where the population consumes a lot of olive oil (Olive oil) in their daily food, the results show that the incidence of coronary heart disease is less frequent than the American population. Olive oil is an oil contains $77 \%$ Mono Unsaturated Fatty Acid (MUFA). In general, monounsaturated fats have beneficial effects on cholesterol levels in the blood, especially when used as a substitute for saturated fatty acids. MUFA is more effective in lowering blood cholesterol levels, than Poly Unsaturated Fatty Acid (PUFA). Mono Unsaturated Fatty Acid (MUFA) is omega-9 (oleic) has more stable properties and better role than PUFA (Omega-3 and Omega-6). PUFA can reduce LDL cholesterol, but can reduce HDL. Instead MUFA can reduce LDL cholesterol and increase HDL cholesterol $(7,9)$.

There have been many studies at the national and international levels relating to physical activity and cholesterol levels, but there is still a lot of controversy, because it has different research results, there are states that there are significant relationships and there are also states that the relationship between physical activity with cholesterol levels is not significant. According to research conducted by Maykur there is a significant relationship between physical activity and cholesterol levels. Meanwhile, according to research conducted by Moraleda there is no significant difference in the relationship between physical activity and cholesterol levels (10,11).

Aerobic exercise is a low to moderate intensity of sports activity that is carried out continuously, such as walking, running, cycling and jogging while anaerobic 
exercise is a high intensity activity that requires quick energy in a short time, but cannot be done continuously with a long duration (12).

Moderate intensity exercise which is done in a relatively long time causes fatty acids to be used as energy, this will reduce the chance of synthesis of sterol core, so that cholesterol is not formed excessively. In human, this process of fat degradation occurs in moderate intensity exercise with a duration of exercise of more than 1 hour continuously. So that moderate intensity exercise for more than an hour can degrade fat as energy. Fat degradation is expected to have the effect of reducing excessive cholesterol synthesis, because the cholesterol sterol core is formed from acetyl-CoA molecules derived from fat $(10,13)$.

Exercise is widely recognized and prescribed as a modality for increasing HDL cholesterol and HDL-C containing triglycerides (TG) containing lipoproteins, which are generally abnormal in patients with diabetes and / or insulin resistance. The benefits of exercise on human heart health are clear and consistent, with exercise for risk modification in the prevention of primary and secondary cardiovascular disease and diabetes. At least 30 minutes of moderate to heavy exercise on most days of the week $(14,15)$.

From the above description, the aim of this research is the effect of olive oil (Extra Virgine Olive Oil-EVOO) and moderate intensity exercise on high density lipoprotein (HDL) levels in male wistar rats (Rattus novergicus L) which are fed a highfat diet.

\section{METHODS}

This study is an experimental research. The research design was used a pretest and posttest design with a control group (Pretest and Posttest with Control Group) with simple randomization.

The study was conducted in September 2019 until February 2020 in the Laboratory of Animal Laboratory Maintenance Unit Faculty of Medicine, University of Muhammadiyah North Sumatera (UMSU) Jl. Gedung Arca No. 53 Medan. HDL level examination was conducted at the North Sumatera Provincial Health Laboratory Jl. William Iskandar Pasar V Barat II No.4.

The research samples were minimum of 24 male Wistar strain rats (Rattus novergicus L) selected by simple randomization. The samples were grouped into 4 groups, namely group I as a control who was not given intervention, group II who was given extra virgine olive oil, group III who was given moderate intensity exercise and group IV who was given extra virgine olive oil and moderate intensity exercise. On the high-fatty diet was given using egg yolk at a dose of $5 \mathrm{mg} / 200$ grams BW/day for two weeks. Then the intervention olive oil was given using a feeding tube for 15 days at a dose of 0.9 grams / day / head. For the moderate intensity exercise intervention, the rats swam for 1 minute and 10 seconds and were given $6 \%$ of their average body weight and tied in the tail of the rats.

The data collection technique was obtained based on the results of HDL level examination of male Wistar strain rats (Rattus novergicus L.) which were examined at the Regional Health Laboratory of North Sumatra Province.

The data were analyzed using the Statistical Application Product and Service Solutions (SPSS) version 24 on a computer. Normality test is done first. If the results of Saphiro Wilk normality test and 
homogeneity are normal and do not show a significant difference then proceed with a paired sample test if the value of $p>0.05$ (16). This study has received information passing the ethical review from the KEPK Faculty of Medicine, University of Muhammadiyah of North Sumatera with number 336 / KEPK / FKUMSU / 2020.

\section{RESULT}

Based on research conducted at the Laboratory of the Faculty of Medicine of UMSU regarding the benefits of olive oil (Olive Oil) on HDL (High Density Lipoprotein) levels in the blood of male Wistar strain rats given moderate intensity exercise, the results obtained are as follows:

Table 1. Results of measurement of HDL levels in rats before and 2 weeks after treatment in the Control, P1, P2 and P3 groups (in $\mathrm{mg} / \mathrm{dL}$ )

\begin{tabular}{ccccccccc}
\hline \multicolumn{7}{c}{ GROUP } \\
\hline \multirow{4}{*}{ A } & \multicolumn{1}{c}{ B } & \multicolumn{2}{c}{ C } & \multicolumn{2}{c}{ D } \\
\hline & Pre & Post & Pre & Post & Pre & Post & Pre & Post \\
\cline { 2 - 9 } & 40 & 42 & 53 & 58 & 50 & 54 & 49 & 63 \\
& 38 & 39 & 45 & 40 & 45 & 51 & 39 & 51 \\
HDL & 48 & 49 & 60 & 64 & 42 & 47 & 42 & 53 \\
& 42 & 45 & 52 & 56 & 48 & 53 & 55 & 64 \\
& 50 & 53 & 48 & 51 & 52 & 58 & 54 & 64 \\
& 37 & 39 & 47 & 51 & 43 & 49 & 46 & 57 \\
\hline
\end{tabular}

Information

A. Control group high fat diet

B. Olive oil treatment group + high fat diet (P1)

C. Medium-intensity exercise treatment group + high fat diet (P2)

D. Moderate intensity exercise treatment group + olive oil + high fat diet (P3)

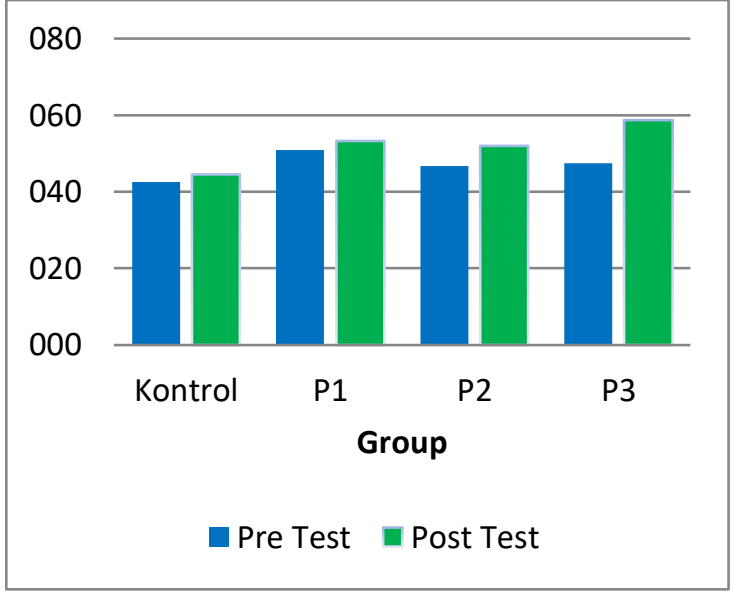

Figure 1. Average bar chart of HDL levels from four groups (in $\mathrm{mg} / \mathrm{dL}$ ) before and after 14 days of treatment.

Based on table 1 and figure 1 , the results of the above study show that for the Pre Test the average HDL level in the control group was $42.50 \mathrm{mg} / \mathrm{dL}$, the olive oil treatment group was $50.83 \mathrm{mg} / \mathrm{dL}$. Moderate intensity exercise treatment group $46.67 \mathrm{mg} / \mathrm{dL}$, and moderate intensity exercise treatment group and olive oil were $47.50 \mathrm{mg} / \mathrm{dL}$. The results of this study for the Post Test the average HDL level in the control group was $44.50 \mathrm{mg} /$ $\mathrm{dL}$, the olive oil treatment group was 53.33 $\mathrm{mg} / \mathrm{dL}$. The moderate intensity exercise treatment group was $52.00 \mathrm{mg} / \mathrm{dL}$, and the moderate intensity exercise treatment group and olive oil were $58.67 \mathrm{mg} / \mathrm{dL}$.

From the table 2, it can be seen that the pre-test average is $42.50 \mathrm{mg}$ / $\mathrm{dL}$ and the post-test average is 44.50 with $\mathrm{P}$ value $<0.05$. From the table 3 , it can be seen that the average pre-test is $50.83 \mathrm{mg} / \mathrm{dL}$ and the post-test average is 55.00 with $\mathrm{P}$ value $<0.05$. 
Table 2. Paired t Test Results for Control

\begin{tabular}{ccc}
\hline $\begin{array}{c}\text { HDL } \\
\text { Cholesterol }\end{array}$ & Average & Value of $\mathbf{P}$ \\
\hline Pre Test & 42.50 & 0.003 \\
Post Test & 44.50 & \\
\hline
\end{tabular}

Table 3. Paired t Test Results for Treatment 1

\begin{tabular}{ccc}
\hline $\begin{array}{c}\text { HDL } \\
\text { Cholesterol }\end{array}$ & Average & Value of $\mathbf{p}$ \\
\hline Pre Test & 50.83 & 0,000 \\
Post Test & 55.00 & \\
\hline
\end{tabular}

Table 4. Paired t Test Results for Treatment 2

\begin{tabular}{ccc}
\hline $\begin{array}{c}\text { HDL } \\
\text { Cholesterol }\end{array}$ & Average & Value of $\mathbf{p}$ \\
\hline Pre Test & 42.67 & 0,000 \\
Post Test & 52.00 & \\
\hline
\end{tabular}

Table 5. Paired t Test Results for Treatment 3

\begin{tabular}{ccc}
\hline $\begin{array}{c}\text { HDL } \\
\text { Cholesterol }\end{array}$ & Average & Value of $\mathbf{p}$ \\
\hline Pre Test & 47.50 & 0,000 \\
Post Test & 58.67 & \\
\hline
\end{tabular}

From the table 4, it can be seen that the pre-test average is $42.67 \mathrm{mg}$ / $\mathrm{dL}$ and the post-test average is 52.00 with $\mathrm{P}$ value $<0.05$. From the table 5 , it can be seen that the average pre-test is $47.50 \mathrm{mg} / \mathrm{dL}$ and the post-test average is 58.67 with $\mathrm{P}$ value $<0.05$.

\section{DISCUSSION}

Based on the results of research conducted in each group using SPPS, showed that there was an influence of Extra Virgine Olive Oil (EVOO) and moderate intensity exercise on HDL levels in male Wistar strain rats (Rattus novergicus L.) who were given a high -fat diet.

In olive oil, based on the results obtained by this study in accordance with previous studies. $(7,17,18)$ This proves that olive oil has an influence on HDL levels in the blood. The presence of MUFA (Mono
Unsaturated Fatty Acid) content in high olive oil has the effect of increasing HDL levels.(5)Fatty acids that have double bonds are easily oxidized. Therefore, MUFA is more stable and has a lower risk of oxidation than PUFA. The high content of monounsaturated fatty acids in olive oil can increase HDL levels in the blood (4). MUFA consists of oleic acid (Omega-9) while PUFA consists of linoleic acid (Omega-6) and linolenic acid (Omega-3). Because oleic acid is a single unsaturated fatty acid, the risk of oxidation is lower than linoleic acid (Omega-6) and linolenic acid (Omega-3). According to previous studies oleic acid (Omega-9) can reduce serum LDL (low density lipoprotein) and increase HDL greater than Omega-3 and Omega-6 (19).

When compared with PUFA, MUFA has a better role because although PUFA is useful for reducing LDL, it has the disadvantage of reducing HDL. Whereas MUFA is able to decrease HDL but is also able to increase HDL. This shows that olive oil can reduce the risk of heart disease (20).

In moderate intensity sports, based on the results obtained by this study, the same as previous studies. This proves that moderate exercise can cause fatty acids to be used as energy and will reduce the chance of sterol core synthesis, so cholesterol is not formed excessively and effectively fat degradation occurs. At the time of moderate exercise intensity with the right duration the body will use energy derived from fat resulting in an increase in HDL levels (10).

So, this study using 4 groups and among the 4 groups in treatment 4 were given olive oil intervention, moderate intensity exercise, and given fat. In treatment 4 after intervention, it was very 
effective in increasing HDL and lowering LDL as shown in the results table.

\section{CONCLUSION}

It can be concluded that olive oil (Extra Virgine Olive Oil), moderate intensity exercise, and olive oil (Extra Virgine Olive Oil) with moderate intensity exercise have the effect on increasing HDL levels in the blood of male wistar rats which were given a high-fatty diet.

\section{ACKNOWLEDGMENT}

The author would like to extend the gratitude to our friends, relatives, colleagues and various parties that we cannot mention one by one who helped us to completing this study.

\section{CONFLICT OF INTEREST}

The author has no conflict of interest and there is no affiliation or connection with or with any entity or organization, which can lead to biased questions in discussions and conclusions of the manuscript.

\section{REFERENCE}

1. Orviyanti G, Murwani H. Perbedaan Pengaruh Yoghurt Susu, Jus Kacang Merah Terhadap Kadar Kolesterol LDL dan Kolesterol HDL Serum Pada Tikus Dislipidemia (Differences in the Effect of the Yogurt Milk, the Juice of Red Beans on the Levels of LDL Cholesterol and HDL Cholesterol Serum in Rats Dyslipidemia). J Kedokt dan Kesehat. 2012;1(1):1-64.

2. Badan Penelitian dan Pengembangan Kesehatan. Riset Kesehatan Dasar. Jakarta; 2013.

3. WHO. Cardiovascular Disease. World Health Organization. World Health Organization; 2017.
4. Syamsu RF. Efek Pemberian Minyak Zaitun (Olive Oil) Terhadap Perubahan Profil Lipid Pada Tikus Putih (Rattus Novergicus) (The Effect of Olive Oil to Changes in The Lipid Profile in White Rats (Rattus Novergicus)). J Farm Univ Muslim Indones. 2017;9(1):75-84.

5. Nugraheni K. Pengaruh Pemberian Minyak Zaitun Ekstra Virgin Terhadap Profil Lipid Serum Tikus Putih (Rattus norvegicus) Strain Sprague Dawley Hiperkolestrolemia (The effect of Extra Virgin Olive Oil on Serum Lipid Profile of White Rats (Rattus norvegicus) Strain of Sprague

Dawley Hipercholestrolemia). Universitas Diponegoro; 2012.

6. Rahmawati M, Nisa K. Pengaruh Asupan Bubur Kacang Kedelai Dan Latihan Intensitas Sedang Terhadap Kadar LDL Kolesterol Tikus Putih (Rattus norvegicus) Jantan Galur Wistar Yang Diberi Diet Tinggi Lemak (The influence of the Intake of Porridge of Soybeans and Moderate Intensity Exercise Versus LDL Cholesterol Levels of White Rats (Rattus norvegicus) Male Wistar Strain Fed a High-Fat Diet). Med J Lampung Univ. 2012;1(1):74-84.

7. Susilo TY. Khasiat Minyak Zaitun (Olive Oil) dalam Meningkatkan Kadar HDL (High Density Lipoprotein) Darah Tikus Wistar Jantan (Efficacy of Olive Oil in Improving the Levels of HDL (High Density Lipoprotein) Blood of Male Wistar Rats). Universitas Jember; 2012.

8. Ma'rufi R, Rosita L. Hubungan Dislipidemia dan Kejadian Penyakit 
Jantung Koroner (The Relationship of Dyslipidemia and the Incidence of Coronary Heart Disease). J Kedokt dan Kesehat Indones. 2014;6(1):4653.

9. Katsarou AI, Kaliora AC, Chiou A, Kalogeropoulos N, Papalois A, Agrogiannis G, et al. Amelioration Of Oxidative and Inflammatory Status in Hearts Of Cholesterol-fed rats Supplemented With Oils or Oilproducts With Extra Virgin Olive Oil Components. Eur J Nutr. 2015;55(3):43-57.

10. Masykur MB, Nisa K, Mayang CS. Pengaruh Asupan Bubur Kacang Tanah dan Latihan Intensitas Sedang Terhadap Kadar HDL Kolesterol Tikus Putih (Rattus Norvegicus) Jantan Galur Wistar Yang Diberi Diet Tinggi Lemak (The influence of the Intake of Bean Pulp Soil and Moderate Intensity Exercise on Levels of HDL Cholesterol White Rats (Rattus Norvegicus) Male Wistar Strain Fed a High-Fat Diet). Pros SNSMAIP III. 2012;3(3):35563.

11. Moraleda R, Belén A, Candela G, José P, Study P, Moraleda BR, et al. Can the exercise mode determine lipid profile improvements in obese patients ? 2013;607-17.

12. Palar CM. Manfaat Latihan Olahraga Aerobik Terhadap Kebugaran Fisik Manusia (Benefits of Exercise Aerobic Exercise on The Physical Fitness of The Human). J eBiomedik. 2015;3(April):316-21.

13. Sponder M, Campean IA, Dalos D, Emich M, Fritzer-szekeres M, Litschauer B, et al. Effect of longterm physical activity on PCSK9, high-And low-density lipoprotein cholesterol, and lipoprotein(a) levels: A prospective observational trial. Polish Arch Intern Med. 2017;127 127(7-8):506-11.

14. Blazek A, Rutsky J, Osei K, Maiseyeu A, Rajagopalan S. Exercise-mediated changes in highdensity lipoprotein: Impact on form and function. Vol. 166, American Heart Journal. Mosby, Inc.; 2013. p. 392-400.

15. Wang Y, Xu D. Effects of aerobic exercise on lipids and lipoproteins. Lipids Health Dis. 2017;16(1):1-8.

16. Dahlan MS. Statistik Untuk Kedokteran dan Kesehatan. 2014.

17. Ninaprilia Z, Kurniawaty E. Effect Extra Virgin Olive Oil And Honey Of Total Cholesterol In White Rats (Rattus Norvegicus) Male Sprague Dawley Strain Induced By High Cholesterol Diet. J Kedokt Univ Lampung. 2013;1(1):178-87.

18. Hendarsyah F, Kurniawaty E, Mustofa S. Comparison of The Effects of Extra Virgin Olive Oil, Honey, and Combination on Blood Levels of HDL in Male White Rats (Rattus norvegicus) Sprague dawley Strain that Induced by HighCholesterol Diet. Med J Lampung Univ. 2014;1(2):55-63.

19. Meisyahputri B, Ardiaria M. Pengaruh Pemberian Kombinasi Minyak Rami Dengan Minyak Wijen Terhadap Kadar Kolesterol High Density Lipoprotein (HDL) Tikus Sprague Dawley Dislipidemia (The Effect of The Combination of Hemp Oil and Sesame Oil on High Density Lipoprotein (HDL) Cholesterol Sprague-Dawley Rats Dyslipidemia). J Nutr Coll. 2017;6(1):35-42. 
20. Daniati AR, Kartasurya MI.

Pengaruh Penambahan Minyak Zaitun Terhadap Tekanan Darah Sistolik Penderita Hipertensi Yang Diberi Jus Tomat (The Effect of the Addition of Olive Oil on Systolic Blood Pressure of Hypertensive Patients Given Tomato Juice). J Nutr Coll. 2015;4(1):62-70. 